\begin{tabular}{c}
\hline sciendo $\frac{\text { ECONOMIC THEMES (2020) 58(1): 17-32 }}{\text { DOI 10.2478/ethemes-2020-0002 }}$ \\
\hline
\end{tabular}

\title{
MULTIFUNCTIONALITY OF AGRICULTURE AS A SIGNIFICANT FACTOR FOR SUSTAINABLE RURAL DEVELOPMENT OF THE REPUBLIC OF SERBIA
}

\section{Lela Ristić}

University of Kragujevac, Faculty of Economics, Kragujevac, Serbia

$\bowtie$ lristic@kg.ac.rs

\section{Danijela Despotović}

University of Kragujevac, Faculty of Economics, Kragujevac, Serbia

$\bowtie$ ddespotovic@kg.ac.rs

Miloš Dimitrijević

University of Kragujevac, Faculty of Economics, Kragujevac, Serbia

$\triangle$ mdimitrijevic@kg.ac.rs

UDC

338.43

(497.11)

Original

scientific paper

Received: 29.08.2019 Accepted: 28.04.2020

\begin{abstract}
The need for a modern agricultural development conditioned the concept of multifunctionality of agriculture. Multifunctionality of agriculture is often considered as a useful tool for achieving economic and sustainable development goals. It is increasingly gaining importance in the field of sustainable rural development by linking traditional and contemporary agricultural functions. Namely, sustainability of development requires food for people, but also other positive social, ecological and economic effects. The aim of this paper is to identify the most important indicators of agriculture from the point of multifunctionality of agriculture as a factor for sustainable rural development of the Republic of Serbia, and also compare rural indicators of the Western Balkan countries. The multivariate linear regression in the paper showed that more indicators of agriculture have impact on economy than on sustainable development of the Republic of Serbia, with particularly significance of rural population and its activity. Thereby, some statistical tests showed a decrease in rural population and employment in agriculture of the Western Balkan countries. It is concluded that support to multifunctionality of agriculture is of particular importance for sustainable rural development of the Republic of Serbia.
\end{abstract}

Keywords: multifunctionality of agriculture, agricultural sector, sustainable development, rural development, Republic of Serbia, Western Balkans.

JEL classification: 013, Q01, R11 


\section{Introduction}

The need for a new approach in development of economy and agriculture in rural areas has imposed the concept of multifunctional agriculture. This required activities focused on increasing production based on agriculture, and other benefits of rural living, such as environmental protection and the provision of services to the local community and society as whole (Pejanović \& Vujović, 2008, p. 6-7). This concept is gaining in importance because it is focused on multifunctional agriculture which enables food for people, employment, raw materials for industry, market for some industrial products, positive balance of trade, environmental protection, social function in the emergency conditions, etc. Thereby, multifunctional agriculture encourages rural diversification, especially development of non-agricultural activities based on agricultural raw materials. Thus, it enables reduction of poverty in rural areas, as well as new investment and other benefits.

The subject of this research is the role and importance of multifunctional agriculture for sustainable rural development of the Republic of Serbia.

The aim of this paper is to identify the most important indicators of agriculture from the point of multifunctionality of agriculture as a factor for sustainable rural development of the Republic of Serbia, and also compare rural indicators of the Western Balkan countries.

The hypothesis from this paper is: Multifunctionality of agriculture will be a significant factor for sustainable rural development of the Republic of Serbia, if in addition to agricultural primary function of producing food, other functions of agriculture will be developed and stimulated.

\section{Literature Review}

Agriculture can be mono-functional, profit-oriented or multifunctional (Šomođi, 2005/06, p. 27). The term "multifunctional agriculture" first appeared on the international scene in 1992 at the Summit of Earth in Rio. The emergence of the concept of multifunctionality responds to a wide range of concerns about significant, worldwide changes in agriculture and rural areas. Multifunctionality of agriculture defines as follows: "Beyond its primary function of producing food and fibre, agricultural activity can also shape the landscape, provide environmental benefits such as land conservation, the sustainable management of renewable natural resources and the preservation of biodiversity, and contribute to the socioeconomic viability of many rural areas. Agriculture is multifunctional when it has one or several functions in addition to its primary role of producing food and fibre" (Huylenbroeck et al., 2007, p. 6). 
Besides its primary function of supplying food and fibre, agriculture provides various other benefits such as environmental goods, food security, food safety, and rural development. Recognition of this has led to the development of the multifunctionality concept (Lehmann et al, 2009). Linking multifunctionality of agriculture with sustainable rural development indicates that agriculture could contribute to socio-economic and environmental development of rural areas.

It is considered that agriculture can be multifunctional if it provides other benefits besides food production (Šomođi, 2005/06, p. 26). Multifunctional agriculture could become one of the key economic branches, but have to be based on knowledge, modern technologies to ensure safe and innovative products, by respecting the principles of responsible resource management (Ristić, 2016).

According to Casini et al. (2012), multifunctionality is a direct reflection of the extent to which local actors succeed in converting local resources into added value for the local system by formulating adequate strategies. This have expression of an overall style of living and strong impact on rural development, through the interconnection among the local actors, determined by the various activities.

Connection of different functions of agriculture and rural areas was defined as "encompassing within the same legal and policy framework: agricultural adjustment and development, economic diversification - notably small and medium scale industries and rural services - the management of natural resources, the enhancement of environmental functions and the promotion of culture, tourism and recreation", where agriculture is and must remain a major interface between people and environment. Unlike of focus of multifunctionality on nature protection, environmental concerns and landscape conservation, other dimensions of multifunctionality, such as community services, renewable energy sources, recreation and linkages with non-agricultural development (for example in gastronomy and tourism) have been largely neglected (Knickel et al., 2009a).

Most governments have been unable to turn multifunctional activities into a real development option. Multifunctionality of agriculture must add income, contribute to the construction of a new agricultural sector that corresponds to the needs of the wider society and it must reconfigure rural resources in ways that lead to wider rural development benefits (Mardsen \& Sonnino, 2008). Thereby, multifunctional agriculture and promotion of efficient resource allocation is a prerequisite for sustainable development (Hediger \& Knickel, 2009).

The recognition of multifunctional agriculture involves a large number of institutions and social groups that do not necessarily all fall within the agricultural sphere, and requires the principles of political, economic, technical and social action to be renegotiated within the territory in question (Dufour et al., 2007).

Multifunctionality requires new forms of organization and cooperation in agriculture. Thereby, sustainability and multifunctionality are linked through the 
influence on resources (Cairol et al., 2009, p. 277). A contemporary challenge is to link the dimensions of agricultural and rural change, and contribute to a socially, environmentally and economically balanced development (Knickel \& Renting, 2000, p. 526).

Figure 1. Agriculture for sustainable development

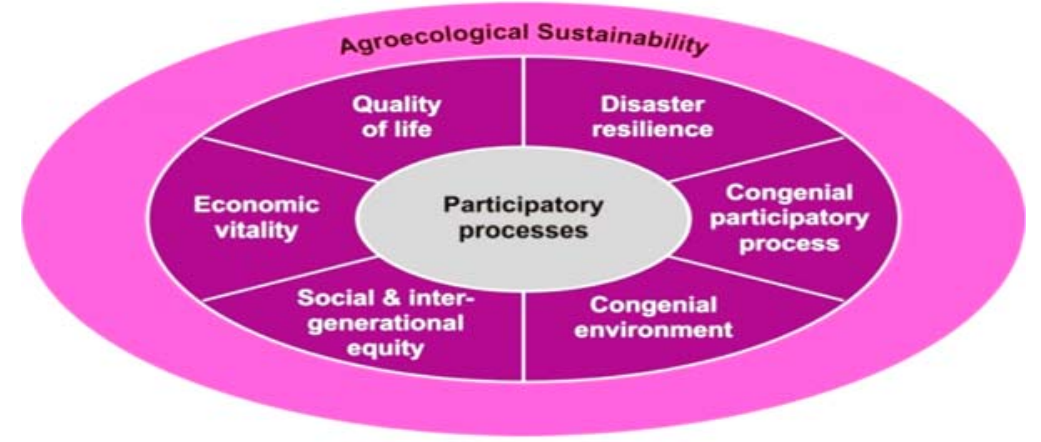

Source: Tripathi et al., 2015, p. 244

In some countries, multifunctionality of agriculture is widely recognized and plays a core role in agricultural and rural policies (Fig. 1), while in other settings its use is marginal and subordinate to other concepts. Anyway, in many countries, social and economic functions of agriculture attract much attention (Renting et al., 2008, p. 367).

Today, sustainable agriculture is gaining in importance, implies rational use of natural resources (Stojanović, 2016, p. 7) and other socio-economic benefits. When meeting the needs of the population, the concept of sustainability comes to the forefront to provide intergenerational equity. Sustainable development is gaining in importance, because population is growing faster than the ability to provide food for them, which affects the increasingly degraded environment (Pušić, 2012, p. 427). Sustainable development as a modern concept which coordinates economic, ecological and socially interests of present and future generations is very applicable in rural areas. Rural areas in the Republic of Serbia, besides limiting factors, also have significant resources (natural resources) for the implementation of the concept of sustainable development (Ristić, 2013, p. 229). In order to achieve sustainable rural development, ecological dimension is of particular importance (Đekić, 2010). Sustainable rural development is a multidimensional and complex developmental concept of synergetic harmonization of economic, social and environmental aspects of the development of rural areas, which requires multifunctionality of agriculture. The essence of it is to improve the quality of life of population and environmental protection (Pugliese, 2001). 
In the literature, the following approaches in the selection of rural development indicators are often used (UN, 2007, p. 143):

- Sectoral - a focus is on agriculture during the selection of rural development indicators. This approach is mainly used in the developing countries.

- Territorial - a focus is on the dispersion of non-agricultural activities. This approach is mainly used in the developed countries.

Considering the specificities of agriculture and rural economy in the Republic of Serbia, as well as the aim of this paper, which is focused on indicators and multifunctionality of agriculture, a sectoral approach will be used.

Importance of agriculture for economic development show many indicators:

- Agricultural population share in total population and active agricultural population share in total active population;

- Agricultural share in the formation of gross domestic product;

- Share of agriculture in international trade;

- Share of agriculture in employment;

- Share of investments in agriculture in total economic investments.

As it regards of the function agriculture "share in foreign trade", for example, Figure 2 and Table 1 show that the exports of agro-food products of the Republic of Serbia is constantly higher than imports. There is high coverage of imports by exports, which in some years was more than twice.

Figure 2. Agriculture exports and imports in the Republic of Serbia

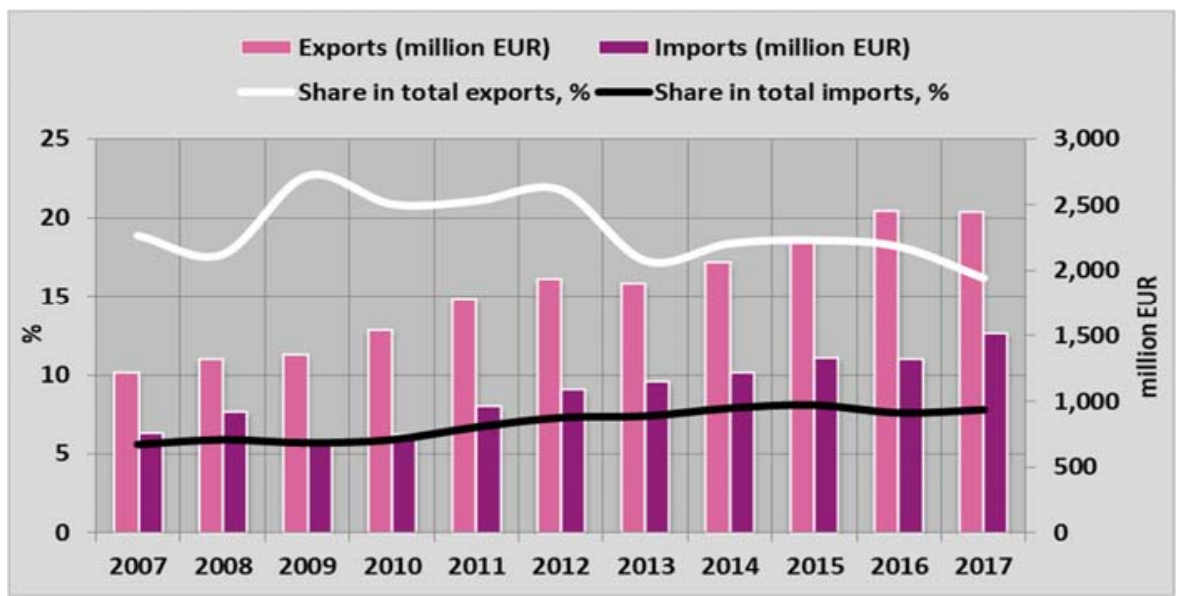

Source: Authors', based on SORS 
Table 1. Agricultural exports and imports of the Republic of Serbia

\begin{tabular}{rcrrrrr}
\hline & $\begin{array}{c}\text { Exports } \\
\text { (million } \\
\text { EUR) }\end{array}$ & $\begin{array}{c}\text { Imports } \\
\text { (million } \\
\text { EUR) }\end{array}$ & $\begin{array}{c}\text { Share in } \\
\text { total } \\
\text { exports, \% }\end{array}$ & $\begin{array}{c}\text { Share in } \\
\text { total } \\
\text { imports, \% }\end{array}$ & $\begin{array}{c}\text { Balance } \\
\text { of trade } \\
\text { (million } \\
\text { EUR) }\end{array}$ & $\begin{array}{c}\text { Coverage of } \\
\text { imports by } \\
\text { exports, \% }\end{array}$ \\
\hline 2007 & $1,220.00$ & 755.3 & 18.9 & 5.6 & 464.7 & 161.5 \\
\hline 2008 & $1,315.80$ & 917.4 & 17.7 & 5.9 & 398.4 & 143.4 \\
\hline 2009 & $1,351.80$ & 663.6 & 22.7 & 5.7 & 688.2 & 203.7 \\
\hline 2010 & $1,542.50$ & 745.1 & 20.9 & 5.9 & 797.3 & 207.0 \\
\hline 2011 & $1,776.90$ & 961.9 & 21.1 & 6.7 & 815 & 184.7 \\
\hline 2012 & $1,930.20$ & $1,092.80$ & 21.8 & 7.3 & 837.4 & 176.6 \\
\hline 2013 & $1,900.70$ & $1,150.40$ & 17.3 & 7.4 & 750.3 & 165.2 \\
\hline 2014 & $2,058.40$ & $1,220.30$ & 18.4 & 7.9 & 838.1 & 168.7 \\
\hline 2015 & $2,230.90$ & $1,331.40$ & 18.6 & 8.1 & 899.5 & 167.6 \\
\hline 2016 & $2,450.90$ & $1,317.60$ & 18.2 & 7.6 & $1,133.10$ & 186.0 \\
\hline 2017 & $2,444.90$ & $1,515.30$ & 16.2 & 7.8 & 929.6 & 161.3 \\
\hline
\end{tabular}

Source: SORS, Foreign Trade of the Republic of Serbia, for the observed years

Table 2 shows the decline in agricultural population (share in total population) in the Republic of Serbia, as well as the decline of the active agricultural population in the total active population. This fact should be particularly taken into account when adopting a future development concept.

Table 2. Agricultural population of the Republic of Serbia, according to the Census of population

\begin{tabular}{lcccccccc}
\hline & 1948 & 1953 & 1961 & 1971 & 1981 & 1991 & 2002 & 2011 \\
\hline $\begin{array}{l}\text { Share of agricultural } \\
\text { population in the total } \\
\text { population, \% }\end{array}$ & 72.3 & 66.7 & 56.1 & 44 & 25.4 & 17.2 & 10.9 & 6.84 \\
$\begin{array}{l}\text { Share of active agricultural } \\
\text { population in the total active } \\
\text { population, \% }\end{array}$ & 77.13 & 73.52 & 62.76 & 53.61 & 34 & 24.95 & 15.57 & 11.77 \\
$\begin{array}{l}\text { Agricultural population } \\
\text { (in 000) }\end{array}$ & 4720 & 4656 & 4290 & 3719 & 2285 & 1694 & 817 & 491 \\
\hline $\begin{array}{l}\text { Active agricultural population } \\
\text { (in 000) }\end{array}$ & 2563 & 2485 & 2269 & 2069 & 1371 & 1041 & 529 & 271 \\
\hline
\end{tabular}

Source: SORS, Statistical Yearbook, 2010; SORS, Villages in Serbia, Census of Population, Households and Housing 2011 


\section{Research Methodology}

The first level of analysis is focused on the multivariate linear regression, which used the sectoral approach for the selection of rural development indicators (UN, 2007 , p. 143). Namely, the indicators of agriculture relevant to the economic development of the Republic of Serbia are used in this research. Due to the inaccessibility of indicators of the share of agricultural population in the total population and the active agricultural population in the total active population for all observed years, but only for the years of the population census, share of the rural population in the total population was used in this paper. Also, instead of the share of investments in agriculture in total economic investments, due to incomplete data, there is used gross fixed capital formation in agriculture, forestry and fishing. The task of this level of empirical research is to determine the importance of agriculture for economic development, through the impact on the Gross Value Added (GVA) generated by agriculture, but also on the Human Development Index (HDI) like one of the best measure of sustainability of development, which includes education, health and income (Stiglic, 2013, p. 316). The HDI methodology is very useful in order to compare the basic development indicators of Serbia with other countries in the region. The secondary data for this survey were collected from various sources, such as: World Bank, FAOSTAT, Global Economy and Statistical Office of the Republic of Serbia, for the observed years.

Based on indicators for determining the role and importance of agriculture in economic development, in this part of research two models were used:

$\%$ GVA of agriculture $e_{i, t}=\beta_{0}+\beta_{1} \%$ rural population ${ }_{i, t}+\beta_{2} \%$ coverage ratio of imports by the exports $\mathrm{s}_{\mathrm{i}, \mathrm{t}}+\beta_{3} \%$ employment in agriculture $\mathrm{i}_{\mathrm{i}, \mathrm{t}}+\beta_{4} \%$ investment in agriculture $\mathrm{i}_{\mathrm{i}, \mathrm{t}}+\varepsilon_{\mathrm{i}, \mathrm{t}}$;

$\mathrm{HDI}_{\mathrm{i}, \mathrm{t}}=\beta_{0}+\beta_{1} \%$ GVA of agriculture $\mathrm{i}_{\mathrm{i}, \mathrm{t}}+\beta 2 \%$ rural population ${ }_{\mathrm{i}, \mathrm{t}}+\beta 3 \%$ coverage ratio of imports by the exports $\mathrm{s}_{\mathrm{i}, \mathrm{t}}+\beta_{4} \%$ employment in agriculture $\mathrm{i}_{\mathrm{i}, \mathrm{t}}+\beta_{5} \%$ investment in agriculture $\mathrm{i}_{\mathrm{i}, \mathrm{t}}+\varepsilon_{\mathrm{i}, \mathrm{t}}$

where GVA of agriculture expressed in share of GDP, rural population in share of total population, coverage ratio of imports by the exports like export / import ratio, employment in agriculture in share of total employment and investment in agriculture like share in total investment, for the Republic of Serbia $i$ in the year $t$.

Employment in agriculture, as well as the size and structure of the labor force of agricultural households, are factors that have a crucial impact on the dynamics of structural changes in agriculture and its overall development (Bogdanov \& Babović, 2014, p. 263). When comparing the Republic of Serbia with other countries, it is noted that the share of agriculture in total employment remains relatively high. Therefore, the second level of analysis carried out with KruskalWallis test to compare the indicators of rural development in the Western Balkan 
countries which are in the process of accession to the EU (except for Croatia which is already a member of the EU), as well as Friedman's test to examine the trends of the observed indicators of rural development in the Western Balkan countries by several consecutive measurements. The secondary data for these analyzes are collected from the databases such as: World Bank, Global Economy and FAOSTAT.

\section{Research Results}

\subsection{Descriptive Statistics}

The multivariate linear regression was used in this paper, in order to examine the importance of rural population and agriculture in international trade, as well as for employment and share of investments in the gross fixed capital formation in agriculture, i.e. the share of agriculture in the formation of GDP and HDI. The observed period in the analysis of the Republic of Serbia is 2007-2017.

Table 3. Descriptive Statistics

\begin{tabular}{lrrrrr}
\hline \hline & $\mathrm{N}$ & Minimum & Maximum & \multicolumn{1}{c}{ Mean } & Std. Deviation \\
\hline $\begin{array}{l}\text { rural_population } \\
\text { coverage_import }\end{array}$ & 11 & 44.06 & 45.67 & 44.7536 & .52891 \\
$\begin{array}{l}\text { export } \\
\text { employment_ }\end{array}$ & 11 & 143.43 & 207.02 & 175.0791 & 19.03523 \\
$\begin{array}{l}\text { agriculture } \\
\text { investment_ }\end{array}$ & 11 & 18.61 & 25.12 & 21.1645 & 2.01773 \\
$\begin{array}{l}\text { agriculture } \\
\text { GVA_agriculture }\end{array}$ & 11 & 3.00 & 4.34 & 3.5727 & .42760 \\
HDI & 11 & 6.01 & 9.00 & 7.7227 & .95145 \\
Valid N (list wise) & 11 & .75 & .79 & .7709 & .01300 \\
\hline \hline
\end{tabular}

Source: Authors', based on data from the World Bank, FAOSTAT, Global Economy and SORS

Table 3 shows that the values in the Republic of Serbia for the share of rural populations in total population range from 44.06 to 45.67 , whereby the highest value was in 2007 (45.67) and the lowest in 2017 (44.06). The share of the rural population in total population records a constant decrease from year to year and has a declining trend. The arithmetic mean for the observed years is 44.75 , and the standard deviation (the average deviation of all values from the arithmetic mean) is 0.52 . The largest oscillations (the highest standard deviation from the arithmetic mean) were recorded in the coverage of imports by exports (19.03). The lowest value was 143.43 in 2008 , and the highest was 207.02 in 2010. Since then, the coverage of imports by exports has had an oscillating trend, but mostly with a downward trend. The second largest oscillations of average values were in 
employment in agriculture (2.01), where the lowest employment was 18.61 in 2016, and the highest was 25.12 in 2008, since the declining trend with mild oscillations was recorded. The value of investments in gross fixed capital formation in agriculture ranged from 3\% in 2016 and 2017 to $4.34 \%$ in 2011, since they were constantly lower with less oscillation. The share of agriculture in the creation of GVA was the lowest in 2017 (6.01\%), and the highest in 2011 (9.00\%). Until then, there was a slight growth, and after 2011 the trend was declining. The HDI recorded the least deviation $(0.01$ from 0.77$)$, with the values that were at the lowest level in 2007 (0.75), and the highest in 2017 (0.79). Thereby, the HDI recorded a rising trend.

\subsection{Regression Analysis}

The influence of agriculture on economic development of the Republic of Serbia was tested by using multivariate linear regression. Namely, the impact of the independent variables (rural population, the coverage of import by exports, employment in agriculture and investments in gross fixed capital formation in agriculture) on the dependent variable (GVA generated by agriculture, as a percentage of GDP) was tested.

Table 4. Significance of agriculture for economic development of the Republic of Serbia

\begin{tabular}{|c|c|c|c|c|c|}
\hline \multirow{2}{*}{ Model } & \multicolumn{2}{|c|}{$\begin{array}{l}\text { Unstandardized } \\
\text { Coefficients }\end{array}$} & \multirow{2}{*}{$\begin{array}{c}\begin{array}{c}\text { Standardized } \\
\text { Coefficients }\end{array} \\
\text { Beta }\end{array}$} & \multirow{2}{*}{$\mathrm{T}$} & \multirow{2}{*}{ Sig. } \\
\hline & B & $\begin{array}{l}\text { Std. } \\
\text { Error }\end{array}$ & & & \\
\hline (Constant) & -38.914 & 9.743 & & -3.994 & .007 \\
\hline rural_population & .951 & .237 & .529 & 4.006 & $.007 *$ \\
\hline $\begin{array}{l}\text { coverage_import } \\
\text { export }\end{array}$ & -.010 & .005 & -.193 & -1.980 & $.095^{* * *}$ \\
\hline $\begin{array}{l}\text { employment_ } \\
\text { agriculture }\end{array}$ & .005 & .067 & .010 & .070 & .946 \\
\hline $\begin{array}{l}\text { investment__ } \\
\text { agriculture }\end{array}$ & 1.582 & .246 & .711 & 6.437 & $.001^{*}$ \\
\hline
\end{tabular}

a. Dependent Variable: GVA_ agriculture

Note: The value is significant at $1 \%(*), 5 \%(*)$, and $10 \%(* * *)$ confidence level

Source: Authors' research

The selected model in the Table 4 is valid for testing the observed variables $(\mathrm{p}=.000)$. Multivariate linear regression shows that for the GVA of agriculture $(\%$ of GDP) the highest statistical significance has investments in gross fixed capital 
formation in agriculture $(\mathrm{p}=.001)$, then the share of the rural population in total population $(\mathrm{p}=.007)$ and finally the coverage of import by export $(\mathrm{p}=.095)$.

The selected model (Table 5) within this research is also valid for examining the impact of all observed agricultural indicators on sustainable development $(\mathrm{p}=$ .003 ). The effect of agriculture on sustainable development was analyzed by using multivariate linear regression, where the dependent variable takes the HDI as an indicator that best reflects the sustainability of development (Stiglic, 2013, p. 316). The independent variables in this case are: rural population, coverage of imports by export, employment in agriculture, investments in gross fixed capital formation in agriculture, and GVA of agriculture (\% of GDP).

Table 5. Significance of agriculture for the sustainable development of the Republic of Serbia

\begin{tabular}{|c|c|c|c|c|c|}
\hline \multirow{2}{*}{ Model } & \multicolumn{2}{|c|}{$\begin{array}{l}\text { Unstandardized } \\
\text { Coefficients }\end{array}$} & \multirow[t]{2}{*}{$\begin{array}{l}\text { Standardized } \\
\text { Coefficients }\end{array}$} & \multirow{2}{*}{$\mathrm{T}$} & \multirow{2}{*}{ Sig. } \\
\hline & $\mathrm{B}$ & $\begin{array}{l}\text { Std. } \\
\text { Error }\end{array}$ & & & \\
\hline (Constant) & 2.053 & .307 & & 6.690 & .001 \\
\hline rural_population & -.029 & .007 & -1.172 & -3.845 & $.012 * *$ \\
\hline $\begin{array}{l}\text { coverage_import } \\
\text { export }\end{array}$ & 4.809E-005 & .000 & .070 & .465 & .661 \\
\hline $\begin{array}{l}\text { employment_- } \\
\text { agriculture }\end{array}$ & .000 & .001 & .046 & .271 & .798 \\
\hline $\begin{array}{l}\text { investment } \\
\text { agriculture }\end{array}$ & -.015 & .011 & -.501 & -1.340 & .238 \\
\hline GVA_agriculture & .006 & .007 & .451 & .916 & .402 \\
\hline
\end{tabular}

a. Dependent Variable: HDI

Note: The value is significant at $1 \%(*), 5 \%(*)$, and $10 \%(* * *)$ confidence level

Source: Authors' research

Based on the Table 5, it is concluded that the share of the rural population in total population has a major impact on sustainable development $(\mathrm{p}=.012)$.

\subsection{Statistical Tests}

Common to all countries of the Western Balkans, including the Republic of Serbia, is that insufficient budget funds are invested in agro-food sector. The capacity for development of this sector is limited by the level of financial investments (Branović, 2016). Neglecting agriculture has resulted in numerous problems that make agriculture uncompetitive and inadequate for sustainable development 
(Milić, 2011, p. 29). Transition brought a lot of additional problems to reforming agricultural sector and increased unemployment of rural labor force. The countries of the Western Balkans also have a problem to ensure sustainable use of rural resources in long term (Bogdanov, 2007). Further research will look at the rural indicators of the Western Balkan countries in the period 2007-2017.

Table 6. Rural indicators comparison of the Western Balkan countries, 2007-2017

\begin{tabular}{|c|c|c|c|c|c|}
\hline & 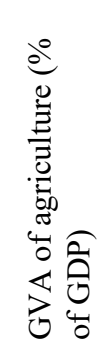 & 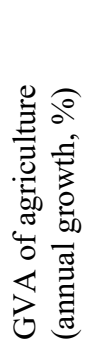 & 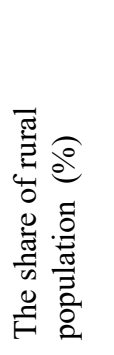 & 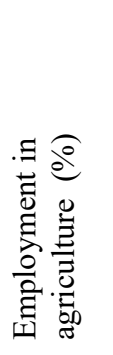 & 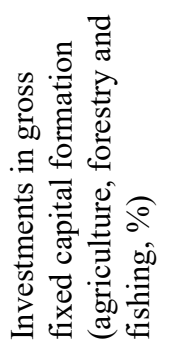 \\
\hline Chi-square & 58.099 & 3.121 & 52.743 & 58.770 & 35.633 \\
\hline Asymp. Sig. & $.000 *$ & .681 & $.000 *$ & $.000 *$ & $.000 *$ \\
\hline Albania & 61.00 & 38.95 & 38.18 & 61.00 & 35.50 \\
\hline $\mathrm{B} \& \mathrm{H}$ & 19.64 & 32.73 & 61.00 & 39.27 & 24.80 \\
\hline Croatia & 6.00 & 26.82 & 36.45 & 16.18 & - \\
\hline \begin{tabular}{ll} 
North \\
\} & 49.00 & 31.82 & 19.82 & 31.45 & - \\
\hline$<$ Montenegro & 32.55 & 38.50 & 6.00 & 6.82 & 5.50 \\
\hline Serbia & 32.82 & 32.18 & 39.55 & 46.27 & 16.20 \\
\hline
\end{tabular}
\end{tabular}

Note: The value is significant at $1 \%(*), 5 \%(*)$, and $10 \%(* * *)$ confidence level

Source: Authors', according to World Bank, Global Economy and FAOSTAT

The Table 6 (Kruskal-Wallis test) shows that agriculture contributes the most to the GDP in Albania, then in North Macedonia, Serbia, Montenegro, B\&H and finally in Croatia. The largest share of the rural population in the total population, after $\mathrm{B} \& \mathrm{H}$ has Serbia, then Albania, Croatia, North Macedonia and finally Montenegro. The largest share of employment in agriculture is in Albania, which also has the largest share of agriculture in GDP. According to the share of employment in agriculture, Serbia is on the second place and according to the share of agriculture in GDP on third place. After Serbia, the highest number of employees in agriculture is in $\mathrm{B} \& \mathrm{H}$, followed by North Macedonia, Croatia and at the end is Montenegro. Serbia is ranked as an agrarian country with a high dependence of rural population employed in agriculture. On the basis of the available data for investments in gross fixed capital formation in agriculture, Albania is ahead, followed by B\&H, Serbia and Montenegro at the end. Data for Croatia and North Macedonia were not available during this research. 
In order to examine the trends of observed indicators in the Western Balkan countries by several consecutive measurements, Friedman's test of successive measurements was used (given that the distribution of the observed indicators is not normal). The mentioned test was used to understand how the observed indicators ranged at the level of all Western Balkan countries and whether they recorded some significant fluctuations and trends year after year.

Table 7. Results of the Friedman's test for the Western Balkan countries

\begin{tabular}{|c|c|c|c|c|c|}
\hline & 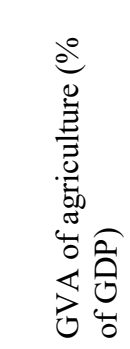 & 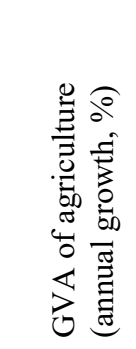 & 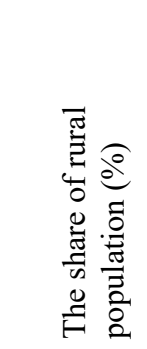 & 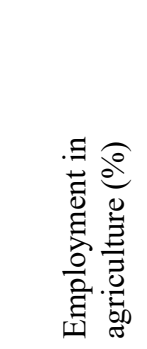 & 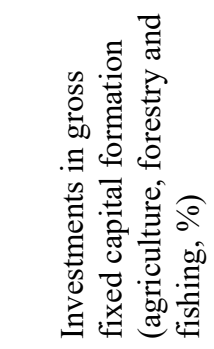 \\
\hline Chi-square & 16.515 & 24.848 & 54.848 & 25.572 & 15.218 \\
\hline Asymp. Sig. & $.086 * * *$ & $.006^{*}$ & $.000^{*}$ & $.004 *$ & $.085 * * *$ \\
\hline 2007 & 5.83 & 5.00 & 10.00 & 8.33 & 2.50 \\
\hline 2008 & 7.67 & 9.83 & 9.50 & 9.33 & 2.00 \\
\hline 2009 & 8.17 & 5.67 & 9.00 & 8.17 & 4.75 \\
\hline 2010 & 7.00 & 5.17 & 8.50 & 7.50 & 6.75 \\
\hline 2011 & 7.17 & 6.50 & 7.50 & 6.75 & 7.50 \\
\hline 2012 & 4.17 & 2.50 & 6.33 & 5.83 & 5.00 \\
\hline 2013 & 7.00 & 9.17 & 5.17 & 5.25 & 7.50 \\
\hline 2014 & 6.33 & 4.83 & 4.00 & 4.17 & 7.00 \\
\hline 2015 & 5.50 & 5.83 & 3.00 & 4.17 & 6.50 \\
\hline 2016 & 5.00 & 7.33 & 2.00 & 3.67 & 5.50 \\
\hline 2017 & 2.17 & 4.17 & 1.00 & 2.83 & - \\
\hline
\end{tabular}

Note: The value is significant at $1 \%(*), 5 \%(*)$, and $10 \%(* * *)$ confidence level

Source: Authors' research

Based on the Table 7, it could be concluded that the share of agriculture in GDP of the Western Balkan countries had mild oscillations, with a slight decline in recent years. The annual growth of the GVA of agriculture had a significant decline in 2012, after which a sharp jump was recorded, and a fall again. The share of rural population has been steadily declining year by year, as well as employment in agriculture since 2008. Investments in gross fixed capital formation in agriculture haven't recorded significant fluctuations, but they had a tendency to grow in relation to the beginning year. 
Unlike the countries of the Western Balkans, the EU countries have more opportunities to develop a modern multifunctional agriculture as a way to contribute sustainable rural development.

\section{Conclusion}

The interaction between multifuncionality of agriculture and sustainable rural development is reflected in that how agriculture provides to society and economy. The focus should be on agriculture's potential to meet new societal demands, such as landscape management, the provision of recreational areas and contributing to the viability of rural areas, and also on developing largely neglected dimensions of multifunctionality (Knickel et al., 2009a).

Multifunctionality of agriculture still is not developed and do not contribute enough to sustainable rural development of the Republic of Serbia, although multifunctional agriculture should be stimulated as an important factor for successful rural development. Many indicators in this research point to the unfavorable position of agriculture in economy and society. The share of agricultural and active agricultural population in the Republic of Serbia is in constant decline. The share of rural population, as well as employment in agriculture in Serbia, i.e. the Western Balkans, is decreasing, although rural population is very important for economy and sustainable development. All this requires more active functions of agriculture, in addition to primary function of producing food.

Transformation requires a visionary perspective with argument that multifunctional agricultural policies lead to a changed and extended perspective, so that (re)productive economy can be developed and established, towards sustainable rural development (Mölders, 2014). Thereby, all innovation policies need to be coherent with the new agricultural and rural agenda (Knickel et al., 2009b).

In this paper, descriptive statistics, i.e. the multivariate linear regression and statistical tests (Kruskal-Wallis test and Friedman's test) showed: rural population of the Republic of Serbia decline; coverage of imports by exports has an oscillating trend, as well as employment in agriculture; investments in gross fixed capital formation in agriculture were constantly lower with oscillations, etc. The GVA generated by agriculture, as a percentage of GDP, and other indicators which were tested for the Western Balkan countries, showed similar problems of these countries and pointed to necessity of support for different functions of agriculture (economic, social and environmental). This confirmed the hypothesis of this research that multifunctionality of agriculture will be a significant factor for the future of sustainable rural development of the Republic of Serbia, if in addition to agricultural primary function of producing food, other functions of agriculture will be developed and stimulated. In doing so, it is essential that agricultural functions bring economic, social or environmental benefits. 


\section{References}

Bogdanov, N. (2007). Mala ruralna domaćinstva u Srbiji $i$ ruralna nepoljoprivredna ekonomija. Beograd: UNDP.

Bogdanov, N., \& Babović, M. (2014). Radna snaga i diverzifikacija prihoda na poljoprivrednim gazdinstvima u Srbiji - stanje i izazovi za politiku ruralnog razvoja. U: Vukmirović, D. (Ed.), Primena podataka popisa poljoprivrede 2012. u analizi stanja poljoprivrede $i$ u planiranju agrarne politike u Republici Srbiji (стр. 262-289). Beograd: Republički zavod za statistiku.

Branović, M. (2016). Poljoprivreda zemalja Zapadnog Balkana u kontekstu EU integracija. Ekonomija - teorija i praksa, 9(4), 33-51.

Cairol, D., Coudel, E., Knickel, K., Caron, P., \& Kröger, M. (2009). Multifunctionality of Agriculture and Rural Areas as Reflected in Policies: The Importance and Relevance of the Territorial View. Journal of Environmental Policy \& Planning, doi:10.1080/15239080903033846

Casini, L., Contini, C., \& Romano, C. (2012). Paths to developing multifunctional agriculture: insights for rural development policies. Int. J. Agricultural Resources, Governance and Ecology, 9(3/4), 185-203.

Đekić, S. (2010). Agrarni menadžment. Niš: Ekonomski fakultet u Nišu.

Dufour, A., Mauz, I., Rémy, J., Bernard, C., Dobremez, L., Havet, A., Pauthenet, Y., Pluvinage, J., \& Tchakérian, E. (2007). Multifunctionality in Agriculture and its Agents: Regional Comparisons. Sociologia Ruralis, doi:10.1111/j.14679523.2007.00444.x

Hediger, W., \& Knickel, K. (2009). Multifunctionality and Sustainability of Agriculture and Rural Areas: A Welfare Economics Perspective. Journal of Environmental Policy \& Planning, doi:10.1080/15239080903412453

Huylenbroeck, G.V., Vandermeulen, V., Mettepenningen, E., \&Verspecht, A. (2007). Multifunctionality of Agriculture: A Review of Definitions, Evidence and Instruments. Living Reviews in Landscape Research, doi: 10.12942/lrlr-2007-3

Knickel, K., \& Renting, H. (2000). Methodological and Conceptual Issues in the Study of Multifunctionality and Rural Development. Sociologia Ruralis, doi:10.1111/14679523.00164

Knickel, K., Brunori, G., Rand, S., \& Proost, J. (2009b). Towards a Better Conceptual Framework for Innovation Processes in Agriculture and Rural Development: From Linear Models to Systemic Approaches. The Journal of Agricultural Education and Extension, doi:10.1080/13892240902909064

Knickel, K., Kröger, M., Bruckmeier, K., \& Engwall, Y. (2009a). The Challenge of Evaluating Policies for Promoting the Multifunctionality of Agriculture: When "Good" Questions Cannot be Addressed Quantitatively and "Quantitative Answers are not that Good." Journal of Environmental Policy \& Planning, doi:10.1080/15239080903033945

Lehmann, P., Schleyer, C., Wätzold, F., \& Wüstemann, H. (2009). Promoting Multifunctionality of Agriculture: An Economic Analysis of New Approaches in Germany. Journal of Environmental Policy \& Planning, doi:10.1080/15239080903033879

Marsden, T., \& Sonnino, R. (2008). Rural development and the regional state: Denying multifunctional agriculture in the UK. Journal of Rural Studies, doi:10.1016/j.jrurstud.2008.04.001 
Milić, B. (2011). Ruralni razvoj - praktikum za lokalne aktere. Beograd: SKGO.

Mölders, T. (2014). Multifunctional Agricultural Policies: Pathways towards Sustainable Rural Development? International Journal of Sociology of Agriculture \& Food, 21(1), 97-114.

Pejanović, R., \& Vujović, S. (2008). Ruralni razvoj i agroturizam. Agroekonomika, 37 (38), 515.

Pugliese, P. (2001).Organic Farming and Sustainable Rural Development: A Multifaceted and Promising Convergence. Sociologia Ruralis, doi: 10.1111/1467-9523.00172

Pušić, Lj. (2012). Da li je ideja o održivom razvoju održiva? Teme, 36(2), 425-442.

Renting, H., Oostindie, H., Laurent, C., Brunori, G., Barjolle, D., MoxnesJervell, A., Granberg, L., \& Heinonen, M. (2008). Multifunctionality of agricultural activities, changing rural identities and new institutional arrangements. Int. J. Agricultural Resources, Governance and Ecology, 7(4/5), 361-385.

Ristć, L. (2016). Spoljni izazovi agrara Republike Srbije. U: Leković, V. (Ed.), Institucionalne promene kao determinanta privrednog razvoja (str. 211-229). Крагујевац: Ekonomski fakultet Univerziteta u Kragujevcu.

Ristić, L. (2013). Strategijsko upravljanje održivim ruralnim razvojem u Republici Srbiji. Ekonomski horizonti, doi: 10.5937/ekonhor1303229R

Šomođi, Š. (2005/06). Neke karakteristike multifunkcionalne poljoprivrede. Agroekonomika, 34 (35), 25-33.

Stiglic, J. (2013). Slobodan pad. Novi Sad: Akademska knjiga.

Stojanović, Ž. (2016). Konkurentnost agrosektora, mere i inovativnost. U: Stojanović, Ž. \& Bogdanov, N. (Eds.), Stanje i perspektive agroprivrede $i$ sela u Srbiji (str. 1-19). Beograd: Univerzitet u Beogradu, Ekonomski fakultet.

Tripathi, N., Singh, R. K., Pal, D., \& Singh, R. S. (2015). Agroecology and sustainability of agriculture in India: An overview. EC Agriculture, 2(1), 241-248.

UN (2007). The Wye Group Handbook: Rural Households Livelihood and Well-Being Statistics on Rural Development and Agriculture Household Income. New York and Geneva: UN, Retrieved from: http://www.fao.org/docrep/015/am085e/am085e.pdf, Accessed: 24. April, 2019.

\section{MULTIFUNKCIONALNOST POLJOPRIVREDE KAO ZNAČAJAN FAKTOR ODRŽIVOG RURALNOG RAZVOJA REPUBLIKE SRBIJE}

Rezime: Potreba za savremenim razvojem agrara uslovila je koncept multifunkcionalnosti poljoprivrede. Multifunkcionalnost poljoprivrede se često posmatra kao koristan alat za postizanje ciljeva ekonomskog i održivog razvoja. Sve više dobija na značaju u oblasti održivog ruralnog razvoja, povezivanjem tradicionalnih i savremenih funkcija poljoprivrede. Naime, održivost razvoja podrazumeva obezbeđenje hrane za ljude, ali i druge pozitivne društvene, ekološke i ekonomske benefite. Cilj ovog rada jeste utvrđivanje najznačajnijih indikatora poljoprivrede sa stanovišta multifunkcionalnosti poljoprivrede kao faktora održivog ruralnog razvoja Republike Srbije, uz komparaciju ruralnih indikatora zemalja Zapadnog Balkana. Putem multivarijantne linearne regresije u radu je utvrđeno da mnogo više pokazatelja poljoprivrede ima uticaj 
na ekonomiju nego na održivi razvoj Republike Srbije. Pri tome je posebno značajno ruralno stanovništvo i njegova aktivnost, iako statistički testovi ukazuju na smanjivanje ruralnog stanovništva i zaposlenosti u poljoprivredi zemalja Zapadnog Balkana. Zaključuje se da je podrška multifunkcionalnosti poljoprivrede od posebne važnosti za održivi ruralni razvoj Republike Srbije.

Ključne reči: multifunkcionalnost poljoprivrede, agrarni sektor, održivi razvoj, ruralni razvoj, Republika Srbija, Zapadni Balkan.

Acknowledgement: The paper is a part of the research done within the project number III 47005, financed by the Ministry of Education, Science and Technological Development of the Republic of Serbia

\section{Authors' biographies}

Lela Ristić is an associate professor at the University of Kragujevac - Faculty of Economics, where she received her doctor's degree. She teaches the following courses: Economics of Agriculture, Tourism and Environment, Tourism and Agribusiness, Management of Rural Development. The key areas of her scientific research are: sustainable agriculture and rural development, tourism and agribusiness management.

Danijela Despotović is an associate professor at the University of Kragujevac Faculty of Economics, where she received her doctor's degree. She teaches the following courses: Theory and Analysis of Economic Policy, Financing Economic Development, Economic Policy at Crisis Times. Her main research interests include: economic policy and development, policy to improve competitiveness, sustainable development.

Miloš Dimitrijević is research trainee at the Faculty of Economics, University of Kragujevac. He has obtained the academic degrees B.Sc and M.Sc at the University of Kragujevac - Faculty of Economics. He is a Ph.D. student at the University of Kragujevac - Faculty of Economics and a participant of the current project cycle of the Ministry of Education, Science and Technological Development. His main research interests include: sustainable agriculture and rural development, general economy and economic development. 